\title{
NEW CONCEPTS FOR ASSESSMENT OF RANGELAND CONDITION
}

\section{TASK GROUP ON UNITY IN CONCEPTS AND TERMINOLOGY COMMITTEE MEMBERS}

\footnotetext{
E. Lamar Smith

University of Arizona

Tueson, Arizona

1989-94

Chairman 1989-92

Patricia S. Johnson

South Dakota State Univ.

Brookings, South Dakota 1989-94

Chairman 1992-94

George Ruyle

University of Arizona

Tucson, Arizona

1989-94

Fred Smeins

Texas A\&M University

College Station, Texas 1989-94

Dick Loper

Consultant

Lander. Wyoming

1989-94

Dick Whetsell Rancher

Pawhuska, Oklahoma 1989-94

Dennis Child USDA/ARS

Washington, D.C. 1989-92
}

\author{
Phillip Sims \\ USDA/ARS \\ Woodward, Oklahoma \\ 1989-94 \\ Ray Smith \\ Bureau of Indian Affairs \\ Herndon. Virginia \\ 1989-94 \\ Len Volland \\ U.S. Forest Service \\ Portland, Oregon \\ 1989-92 \\ Miles Hemstrom \\ U.S. Forest Service \\ Lakewood, Colorado \\ 1992-94 \\ Everet Bainter \\ Soil Conservation Service \\ Casper, Wyoming \\ 1989-92 \\ Arnold Mendenhall \\ Soil Conservation Service \\ Lincoln, Nebraska \\ 1991-92 \\ Keith Wadman \\ Soil Conservation Service \\ Washington, D.C. \\ 1992-94
}

\author{
Dave Franzen \\ U.S. Fish and Wildifie Service \\ Lakeview, Oregon \\ 1989-91 \\ Milt Suthers \\ U.S. Fish and Wildlife Service \\ Evergreen. Colorado \\ 1991-94 \\ Iohn Willoughby \\ Bureau of Land Management \\ Sacramento, California \\ 1989-91 \\ Ned Habich \\ Bureau of Land Management \\ Lakewood, Colorado \\ 1992-94 \\ Tom Gaven \\ National Park Service \\ San Francisco, California \\ 1992-93 \\ Jennifer Haley \\ National Park Service \\ Boulder City, Nevada \\ 1993-94
}

\begin{abstract}
Range condition score or classification does not tell us, in a general sense, much of what managers and the public want to know about rangelands. Range condition is not a reliable indicator, across all rangelands, of biodiversity, erosion potential, nutrient cycling, value for wildlife species, or productivity. Succession, the basis for the current concept of range condition is not an adequate yardstick for evaluation of rangelands. The Society for Range Management (SRM) established the Task Group on Unity in Concepts and Terminology which has developed new concepts for evalua-
\end{abstract}

Visual esample of sone of these concept will appear in an article to be published in Rangelands Vol. 17(3):85-92, June 1995. tion of the status of rangelands. These concepts are based on the premise that the most important and basic physical resource on each ecological site is the soil. If sufficient soil is lost from an ecological site, the potential of the site is changed. The Task Group made three recommendations, which were adopted by the SRM: 1) evaluations of rangelands should be made from the basis of the same land unit classification, ecological site; 2) plant communities likely to occur on a site should be evaluated for protection of that site against accelerated erosion (Site Conservation Rating, [SCR]); and 3) selection of a Desired Plant Community (DPC) for an ecological site should be made considering both SCR and management objectives for that site.

Key Words: Range Condition, Desired Plant Community, Site Conservation Threshold, Sustainability, Ecological Site, Soil Erosion 
Sustainable land use is the fundamental premise upon which management of rangelands, and other critically important natural resources, is based. The concept that we should manage land to maintain or enhance its productivity for future generations is not new. But seldom in the short history of rangeland management has the "condition" of the rangelands, especially public rangelands, attracted so much attention. One of the stated objectives of the sweeping changes in grazing regulations and grazing fees proposed in Rangeland Reform ' 94 was to "accelerate restoration and improvement of public rangelands" (USDI/USDA. 1994), although no consistent criteria were provided for deciding whether such "improvement" had occurred.

While nearly everyone agrees that early uncontrolled livestock grazing resulted in major impacts on rangeland soils and vegetation, there is little agreement on the measures of status and trends under current management. Most professional rangeland managers and scientists agree with the widely quoted statement of Thad Box that "rangelands are in the best condition they have been in this century." Range condition data (e.g., SRM 1989) indicate that trend in range condition is up or static on about $85 \%$ of U.S. rangelands, public and private. These data, combined with numerous photographic records and personal experience, lead to the conclusion that there has been general improvement in the condition of rangelands since passage of the Taylor Grazing Act.

However, others disagree. Critics point out that the same data show that most public rangelands are in "poor" or "fair" condition and conclude that this situation indicates a failure of current management and a need for drastic action as proposed, for example, in Rangeland Reform ' 94 (USDI/USDA 1994). The data are used as the basis for claiming that soil erosion, wildlife habitat, biodiversity, and other values are being degraded or destroyed on our rangelands as a result of livestock grazing (e.g., Wald and Alberswerth 1985, Comptroller General 1977, Dregne 1983). Even the BLM stated that ranges in "fair" and "poor" condition were "producing far below their potential" and were, therefore, "unsatisfactory" (BLM 1979).

This kind of confusion and disagreement led the Society for Range Management (SRM) to establish, first, the Range Inventory Standardization Committee in 1978 (RISC 1983) and then the Task Group on Unity in Concepts and Terminology (UCT) in 1989. The recommendations in the report of the "Unity" Task Group (UCT 1991) were adopted as policy by the Society for Range Management's Board of Directors in July, 1991. The 1991 report of the Task Group is the basis for the concepts and recommendations presented in this paper. Some additional clarification and literature citations are included in the present report that were not in the original 1991 Task Group Report.

\section{MISSION OF THE TASK GROUP}

The Task Group on Unity in Concepts and Terminology (UCT) was formed in 1989 and assigned the following task:

1. Continue professional dialogue on terminology, ecological concepts, and use interpretations of ecological data relating to rangeland classification, inventory and monitoring.

2. Continue to seek agency commonality and unity in technology and methodology relating to rangeland condition and trend.

3. Based on progress in the first two items, update and publish a follow-up report on "Assessment of Rangeland Condition and
Trend in the United States--1989" (SRM 1989) two years after publication of that report.

4. Review and publish an updated version of glossary terms related to range classification, inventory, and monitoring at the same time as the assignment listed above.

5. Stay in close communication with SRM members on the National Academy of Science committee concerning status and progress.

This report is based on the work of the UCT on the first, second, and fourth of the assignments above. The recommended definitions of terms relating to rangeland assessment are given in Appendix A. After some deliberation, the UCT decided that it would not be useful to pursue the third assignment, updating the SRM's report on range condition, because essentially no additional information was available on which to base such an update. The UCT maintained close liaison with the National Academy of Sciences/National Research Council committee (NAS/NRC) formed at about the same time which eventually published a report on "range health" (NRC 1994). Two members of the UCT also served on the NAS/NRC committee. Copies of all meeting notes, draft reports, definitions, and other work of the UCT were sent to the NAS/NRC committee as they were done. Thus the NAS/NRC committee was fully informed of the direction and progress of the UCT, but this was a one-way exchange. Due to policies of the National Academy of Sciences, the UCT did not see any of the work of the NAS committee until final publication of the Rangeland Health book in 1994. Membership of UCT was chosen to insure representation of major federal agencies conducting rangeland assessments, the academic community, and private industry to provide for different perspectives and opportunity for feedback from a broad cross-section of SRM members and others.

\section{TRADITIONAL RANGE CONDITION ASSESSMENT}

Current approaches to rangeland condition assessment have their roots in the observations of Sampson (1919). He related stages of secondary succession to range condition classes produced by livestock grazing. Heavy grazing caused a shift to lower successional stages and reduction or absence of grazing allowed succession to proceed to higher stages. This model was based on the concepts of succession espoused by Clements (1916). Concepts of rangeland condition and trend and range sites evolved over the next 30 years and were elaborated into operational procedures by Dyksterhuis (1949) and Parker (1954). Concepts and procedures have differed among the various agencies (Soil Conservation Service, Bureau of Land Management, and Forest Service) and have evolved within agencies over time. These differences make it difficult to compare data among agencies or to establish changes over time. Nevertheless, all the approaches used have been founded on the same basic model of Clementsian succession proposed by Sampson (1919), and this remains the basis for evaluating "ecological status" by all three agencies today.

In general, current approaches to rangeland condition rely on comparisons of species composition (relative biomass) of present vegetation compared to the "climax" or "potential natural" vegetation for the site. Vegetation is rated as poor, fair, good, excellent (or as low seral, mid seral, high seral, potential natural) according to its similarity to the climax. Implicit in this approach 
is that "climax" or "potential natural" vegetation is best in terms of stability, diversity, and productivity. Departure from the climax, or retrogression, is generally attributed to livestock grazing and occurs as a result of "years of overgrazing" (Dyksterhuis 1949) or of "grazing intensity" (Stoddart et al. 1975). Reduction or elimination of grazing will result in succession to a higher condition class, ultimately reaching "excellent" or "potential natural" condition. This model reflects a linear, reversible reaction of vegetation to the "disturbance" of grazing.

Problems with the traditional approach to rangejand condition assessment have been amply documented by several authors (Love 1961, Jameson 1970. Smith 1978. Westoby 1980, and others). One problem is that vegetation changes may occur as a result of many factors other than grazing, e.g., fire, lack of fire, extreme weather events, climatic change, invasions of exotic species. Change and "disturbance" appear to be natural features of vegetation, and the concept of a stable "climax" upon which the "balance of nature" paradigm is based may be an illusion (Johnson and Mayeux 1992).

Another problem is that, even where livestock grazing may have been the cause of vegetation change, removal or reduction of livestock grazing will not always result in a return to the "climax" or "original" vegetation. The Clementsian model of predictable and reversible succession seems to apply fairly well in grasslands. Under heavy grazing taller perennial grasses give way to shorter perennial grasses and eventually to annuals and forbs; removal of grazing results in a return to the taller perennial grasses in a relatively short time, particularly if climatic conditions are favorable. However, when shrubs or trees replace the grasses due to heavy grazing (or other "disturbances"), the changes in vegetation may not be spontaneously reversible.

Finally, similarity of species composition to that of the climax has no consistent relationship with soil protection, value for wildlife habitat, biodiversity, or biomass productivity. Soil may be adequately protected from loss by erosion by vegetation which has little resemblance to the "climax." The extreme examples would be seeded stands of exotic species such as crested wheatgrass or Lehmann's lovegrass or invasive species like leafy spurge.

Since wildlife species have a variety of habitat requirements involving both species composition and vegetation structure, one vegetation type obviously cannot be best for all wildlife (Severson and Urness 1994). Shifts from grassland to shrubland, as has happened in the Southwest for example, have benefitted many species of wildlife and probably have resulted in overall greater numbers and diversity of wildlife than existed under "pristine" conditions.

In considering biodiversity, one must specify the scale of interest (West 1993). Species diversity in plant communities is often, if not usually, greater in "seral" stages than in the "climax" stage (Clements 1905, cited by Laycock 1994). Invasion of exotic species may increase diversity rather than decrease it (Johnson and Mayeux 1992). At the landscape level plant species diversity (and therefore probably animal species diversity also) will obviously be greater where a variety of different plant communities (seral stages) occur than where the whole landscape is occupied by the same community. Thus, rangelands with a diversity of "condition classes" may possess higher biodiversity than if all were in "excellent" condition.

The BLM's (BLM 1979) statement that rangelands in poor or fair condition are producing far below their potential or have lost productive potential is not necessarily true. In Arizona range condition class was found to be correlated with livestock forage production but not to total biomass production across a wide cross section of range sites (Frost and Smith 1991). Much of our research and experience in revegetation throughout the West shows that "poor condition" ranges are as productive as ever if the "undesirable species" are removed and "desirable" ones reintroduced.

Various interest groups use range condition reports to imply that (1) a large portion of the rangeland in the U.S. is in poor or fair condition, (2) this condition is the result of livestock grazing and improper management either in the past or currently, (3) fair and poor condition rangelands have lost productivity, are low in diversity, are poor habitat for wildlife, and are "unsustainable", and (4) reduction or removal of livestock would result in the restoration or improvement of these rangelands. While some of these conclusions are true in some cases, they are not true for a large percentage of the rangelands classified in poor and fair condition. Quite simply, there is no way that such conclusions can be drawn from range condition data because the procedures used to assess range condition currently do not produce the information required to reach such conclusions. Current range condition assessment methods do not provide answers to the questions that Congress and the public want answered about the status of our rangelands.

\section{BASIC PREMISES OF THE TASK GROUP}

In approaching their task, the Task Group Unity in Concepts and Terminology (UCT) developed several basic premises upon which its recommendations are based. These were:

1. Rangeland condition assessment should be based on sound ecological principles and scientific information. Traditional range condition assessment relied heavily upon the Clementsian concept of climax and succession. These concepts were largely rejected as general theories by ecologists during the 1970 s and 1980s (see Smith 1989 for a review). A number of alternative models of vegetation dynamics were proposed, but none has been generally accepted. The UCT decided that a new approach to range condition assessment should be based on the best ecological understanding currently available but should not be tied to a specific model of succession.

2. Site potential must be recognized in evaluating rangeland condition status. Differences in soil, topography, and climate are the major determinants of the kind and amount of vegetation which can be produced on a given piece of land, and also the "natural" levels of soil erosion which can be expected. Failure to recognize these site differences results in classifying some land in "poor" condition when it does not have the potential to be any better. This premise is well established in the range profession and is recognized in most (but not all) current rangeland condition assessment.

3. "Sustainability" is the fundamental goal of rangeland management and sustainable management of rangelands depends primarily on conservation of the soil. Management should not result in irreversible reductions of soil productivity if that can be avoided. (UCT recognized that landscape evolution results in degradation of some sites, and also that economic feasibility must be a consideration.) The primary cause of irreversible loss of soil productivity on most rangelands is erosion by wind and water. Thus, 
"sustainability" should be evaluated in an objective way independent of the suitability of vegetation for any particular use or combination of uses. This principle was based on the work of Ellison (1949).

4. If current vegetation on a site meets the requirement to provide adequate soil protection, its desirability should be determined by how well it meets other management goals, not by its presumed successional status. "Pristine" vegetation probably did not reflect a stable condition and will not be "restored" by protection from disturbance. The presumed pristine or climax vegetation is not necessarily "best" for any land use or ecological attribute and therefore is not a necessury, or even particularly useful, standard for setting management goals or assessing rangeland condition.

Based on these four premises the UCT developed the following guidelines for range condition assessment.

\section{ECOLOGICAL SITE}

Rangelands should be classified and mapped on the basis of ecological sites as a basis for range condition assessment, monitoring, and management planning. Ecological site is defined as "a kind of land with specific physical characteristics which differs from other kinds of land in its ability to produce distinctive kinds and amounts of vegetation and in its response to management." Ecological sites should be correlated with phases of soil taxonomic units.

Ecological sites are essentially synonymous with the concept of range sites as used for many years by the Soil Conservation Service and other agencies. Range sites have traditionally been defined on the basis of differences in species composition and/or production of the climax community for the site. With the Unity in Concepts and Terminology Task Force (UCT) definition of ecological sites, any site difference (soil, slope, topographic position) which results in a significant difference in vegetation and/or management response would be the basis for describing a different site. Knowledge of the climax or potential plant community might be helpful, but not necessary. Ecological site was used rather than range site to make clear that this classification system can be used on woodlands, forestlands, or other lands which some might not consider to be "range," and it may apply in all uses and values derived from rangelands, not just for livestack grazing purposes.

The UCT developed an outline for an ecological site description (Appendix B) based on the format currently used for ecological sites (range sites) by the Soil Conservation Service and Bureau of Land Management. The major difference is that the UCT format calls for a description of the known community types which may occur on the site and the processes of transition among them, rather than just one "potential" or "natural" community. This new scorecard represents a "state and transition" model for each ecological site.

\section{SITE CONSERVATION RATING}

To assess the "sustainability" of rangeland management, the Unity in Concepts and Terminology Task Force (UCT) developed the concepts of Site Conservation Rating (SCR) and Site Conservation Threshold (SCT). SCR was defined as "an assessment of the protection afforded a site by the current vegetation against loss of potential." SCT was defined as "the kind, amount, and/or pattern of vegetation needed as a minimum on a given site to prevent accelerated erosion." The "threshold" in this case is in the rate of soil erosion. Vegetation which provides protection equal to or in excess of that necessary to prevent accelerated erosion would be above the threshold and would be rated as "satisfactory" or "sustainable." Vegetation which does not provide adequate protection would be rated "unsatisfactory" or "unsustainable."

Figure 1 illustrates in a schematic way the concept of the Site Conservation Threshold. The $\mathrm{x}$ axis indicates the degree of soil protection afforded on the site. Above some point the erosion rate is relatively constant. The rate of erosion above this point is considered to approximate "natural" erosion or a tolerable rate of erosion determined by clinatic, soil, and topographic factors. As soil protection decreases, erosion rate will increase. The point where erosion rate increases significantly is considered the Site Conservation Threshold (SCT). The SCT is shown as a shaded zone to indicate that the exact point may not be definable. A level of soil protection below the SCT will result in a rate of soil erosion which will eventually result in soil loss sufficient to reduce the productive potential of the site. The shape of the curve shown in Figure 1 is hypothetical only. The "threshold" may not be as distinct as shown, especially where natural rates of erosion are high.

Assuming that most rangeland sites experience some level of natural or geologic erosion, accelerated erosion would increase the rate of erosion to a point of eventually diminishing the productive potential of the site. In other words, site productivity is unsustainable. There are some places where lack of precipitation, soil characteristics, or erosion due to offsite factors make the concept of sustainable productivity unworkable, but these situations are a relatively minor part of the total rangelands resource.

It is not feasible to measure erosion rate directly to arrive at a Site Conservation Rating (SCR). Therefore SCR will have to be based on assessment of attribute(s) of vegetation, or perhaps soil surface features, which can be directly observed in the field and which are indicators of the degree of protection from erosion. The UCT did not specify which attributes should be observed, because these may vary in different ecological regions and from site to site within a region. On many ecological sites, basal cover of perennial vegetation may be a good indicator of degree of erosion protection. For example, on a range site in Arizona, it appears that basal cover of perennial vegetation of about $7 \%$ is required to prevent accelerated erosion (Watters 1993); i.e., basal cover could be the basis for the SCR and a cover of $7 \%$ would constitute the SCT. In other situations. different attributes, such as community type or structure, plant spacing, plant and litter biomass, or other characteristics of vegetation and/or surface soil may be appropriate. For example, Tongway (1994) used multiple factors of vegetation and surface soil characteristics to rate "soil condition," and this approach may have merit in evaluating site conservation rating, especially where perennial vegetation is scant.

These criteria for SCR and SCT will have to be worked out by research and professional judgement for each ecological site and should then be incorporated into the ecological site description. Criteria selected should be objective and quantitative enough to serve as a basis for monitoring so that trends in the SCR can be established as a measure of management effectiveness. 


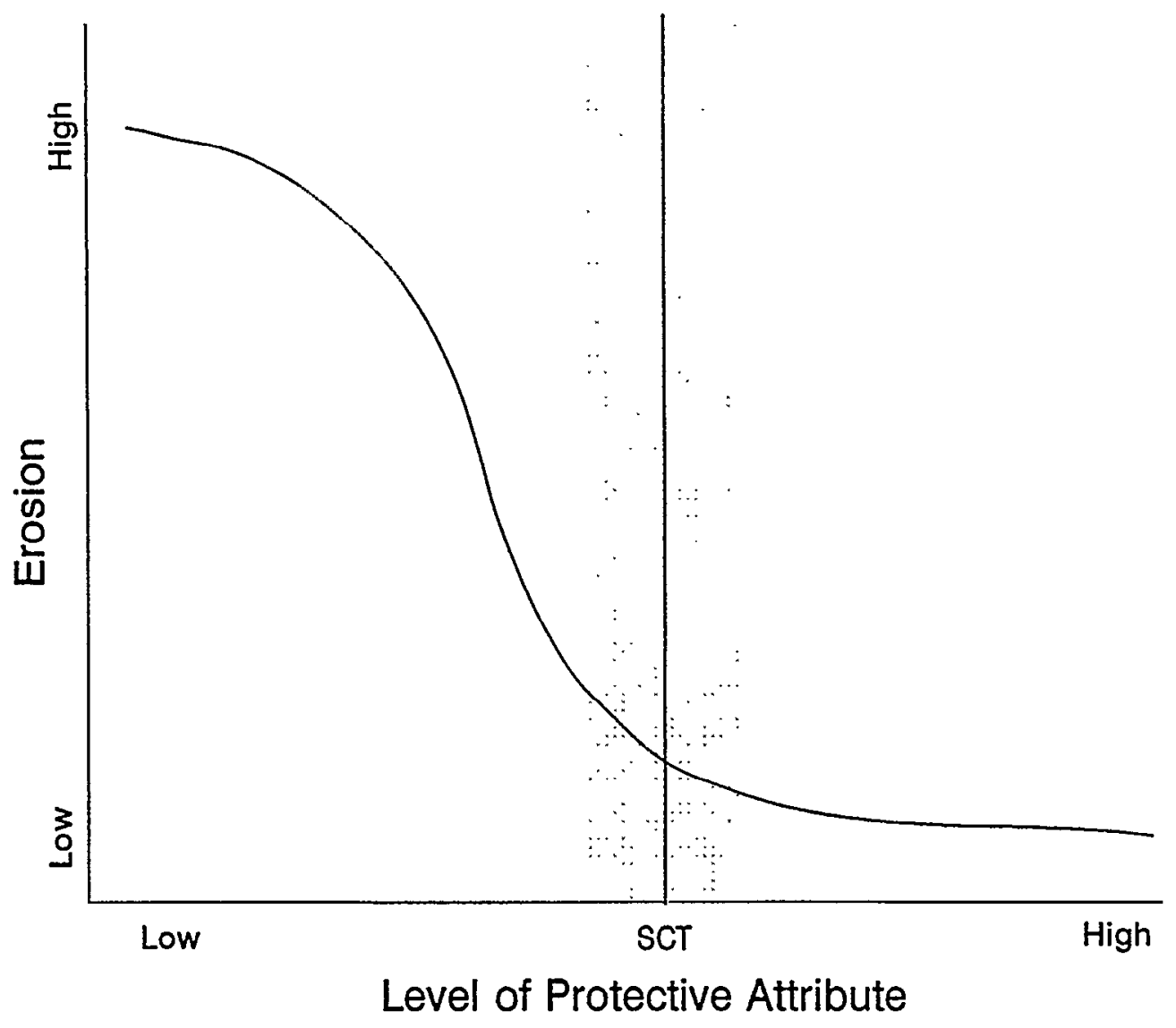

Fig. 1. Hypothetical graph of erosion as a function of a protective attribute (e.g. cover, biomass, density of plants, or other quantifiable attribute). Erosion rates, the protective attribute selected, and levels of that protective attribute are specific to each ecological site. The level of the protective attribute at which erosion rates accelerate is the Site Conservation Threshold (SCT). Since the specific level may be difficult to pinpoint, SCT may be best indicated by the shaded region of the graph.

\section{DESIRED PLANT COMMUNITY}

On any given ecological site there may be several vegetation community types depending on the history and current status of management and natural influences such as fire history. Each of these is capable of being produced at any location on the ecological site if the necessary management actions are taken. The Desired Plant Community (DPC) is defined as "of the several plant communities that may occupy a site, the one that has been identified through a management plan to best meet the plan's objectives for the site." In most cases, a plant community which does not have the capability to protect the site against accelerated erosion (i.e., is below the Site Conservation Threshold [SCT]) would not be chosen as a DPC.

Figure 2 illustrates the concept of multiple community types in relation to the SCT. Plant community types which afford a level of site protection above the SCT are indicated by Roman numerals. All of these community types are capable of being produced on the ecological site. The arrows indicate transitions among them due to natural (successional) processes or management. Any of these might serve as the Desired Plant Community, depending on management objectives. Community types which do not afford an acceptable level of soil protection are indicated by letters. The arrows indicate that these community types may be altered by management to bring them to a type above the threshold. If site protection remains below the threshold long enough, the potential of the site to support the array of plant community types may be irreversibly lost. In this case, a new ecological site with a different potential should be defined.

The shift across the SCT does not necessarily involve a change in community type, as might be inferred from Figure 2. Certain plant community types may be indicators of adequate or inadequate site protection; e.g. Blackburn et al. (1986) found runoff and sediment yield increased as vegetation shifted from oak mottes, to mid grasses, to shortgrasses in the Edwards Plateau. In other cases, the SCT is defined by specific attributes, such as basal cover, which do not necessarily entail a shift in community type, as discussed above.

The DPC concept originated with the BLM in an effort to establish a vegetation goal relevant to management objectives. The "state and transition" model of vegetation change (Westoby et a. 1989) and the threshold concept of vegetation change (Holling 1973, Walker et al. 1981, Noy-Meir and Walker 1986, Laycock 1991, Friedel 1991) are similar to and compatible with the DPC concept described above. The various plant community types possible on an ecological site correspond to the various "states" and the management actions required to move from one 


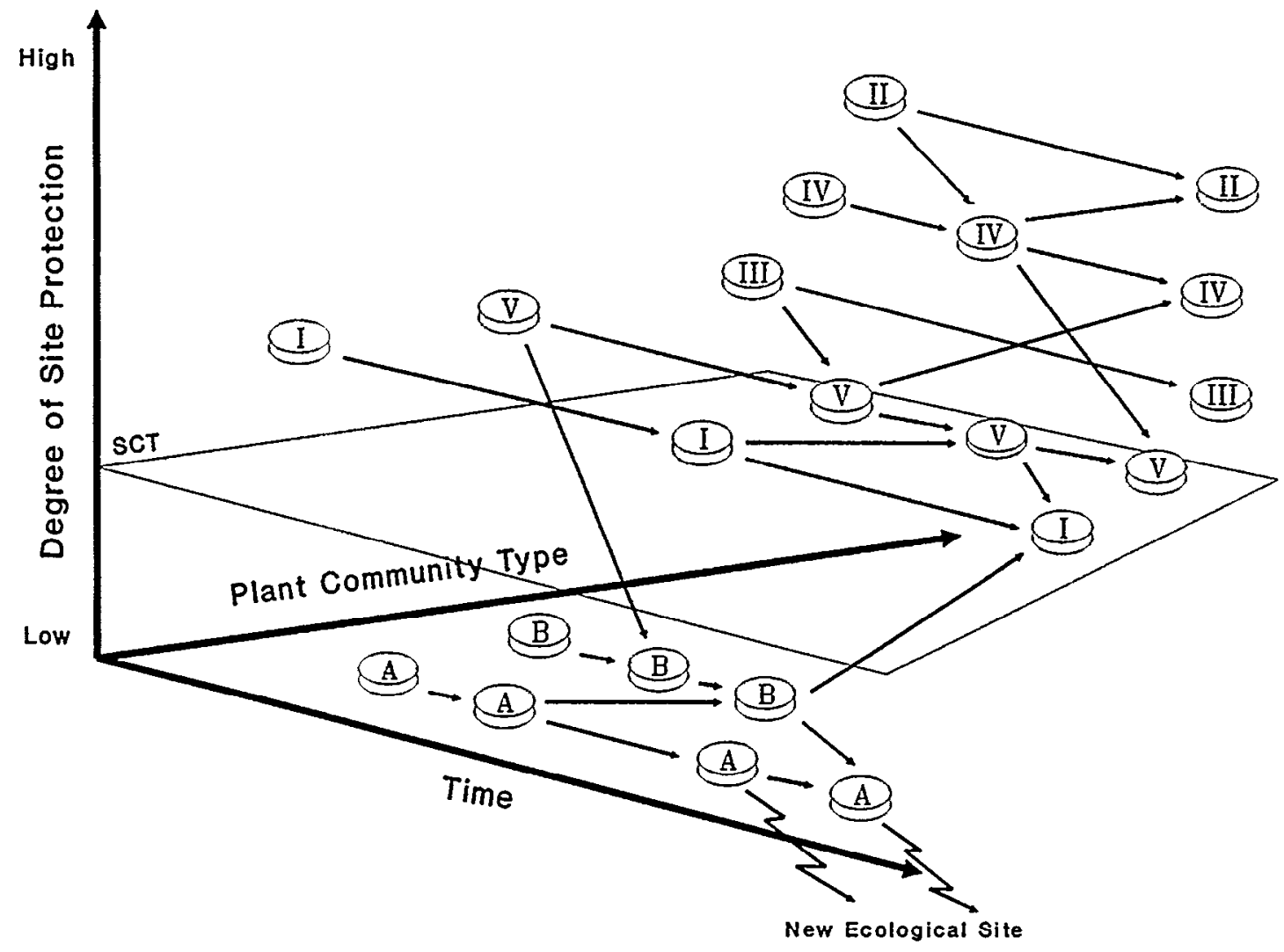

Fig. 2. Multiple community types in relation to the Site Conservation Threshold (SCT) for a hypothetical ecological site. The level of protection afforded the site by one or more protectives attributes (e.g. cover, biomass, density of plants, or other quantifiable attribute) is specific to the ecoogical site. Each disk represents a plant community type which is capable of being produced on the ecological site. The plant community types marked with a Roman numeral provide protection to the site above SCT; those marked with letters do not provide protection above SCT. Arrows indicate hypothetical transitions between plant community types over time. Given sufficient time, accelerated erosion will result in enough soil loss to require the ecological site to be renamed (i.e. New Ecolgical Site) if plant community types below SCT are maintained on the site.

community to another are the "transitions" or "thresholds." Selection of a DPC depends on the relative utility of each state for the uses and values desired for the site, and also the feasibility (economic, legal, and technological) of implementing the required management to change present vegetation to a more desirable type.

Recognizing that rangeland vegetation changes over time in response to various influences, the UCT emphasized that the DPC should be described in fairly general terms. For example, desired plant composition should probably be described more in terms of species life forms or functional groups than by individual species. Also, the DPC should be selected from community types actually observed on the ecological site. In other words, DPC should not be described by taking the most desirable attributes of various communities and combining them into some artificial "ideal community."

Management effectiveness can be assessed by a Vegetation Management Status (VMS) rating which would describe how nearly the present vegetation resembles the desired plant community. More importantly, trend in VMS, described as toward the
DPC, away from DPC, or static will indicate success of current management in reaching management objectives.

Some have expressed concern that the DPC represents a moving target, i.e. that the DPC will change as management objectives change, and thus the ability to hold agencies accountable for long-term management effectiveness will be weakened. We are not overly concerned about this situation for several reasons. First, in our view the main concern that people have for the condition of the rangelands is reflected in the assessment of Site Conservation Rating; i.e. how future options are being maintained. This assessment is not subject to changes in management priorities since, presumably, sustainability is a fundamental objective with a sound ecological base not affected by changing values or economic considerations. Second, VMS will be determined based upon quantitative field observations of specific attributes of vegetation, thus trend in these attributes can be tracked even if the DPC is changed.

\section{RECOMMENDATIONS OF THE TASK GROUP}

The Unity in Concepts and Terminology Task Force made a 
number of recommendations in its report (UCT 1991) and some additional recommendations have been made since 1991. These were as follows:

1. Interagency Working Group for Rangeland Assessment The UCT recommended that the SRM, through its Board of Directors and Executive Vice President, serve as a catalyst to establish a permanent interagency working group to coordinate the implementation of a national rangeland inventory and assessment based on SRM guidelines and to monitor the procedures used and the information developed. UCT believed that such a working group was needed to ensure coordinated and compatible approaches to rangeland classification, inventory, monitoring, and reporting. UCT recommended that all federal agencies having rangeland management responsibility (including National Park Service. Fish and Wildlife Service, Bureau of Indian Affairs, Department of Defense, and others) be included, and that a mechanism for involvement of state agencies and universities at the state level be developed. The SRM should seek to have representation at the national level and serve as reviewer for new or modified procedures when requested.

In February 1994 the UCT made the following recommendation to the Board of Directors: Building upon the SRM Board of Directors' past approval of the recommendation of the Unity Task Group to establish an interagency working group, we recommend that this interagency working group be charged to develop a statistically valid inventory and condition assessment of the rangelands of the United States. This working group is also consistent with the recent National Research Council's recommendation in their Rangeland Health publication (NRC 1994). The assessment should be similar to the National Resources Inventory in design and implementation, thus building on agency expertisc. This inventory must be accomplished through a partnership effort with the Soil Conservation Service, Forest Service, Bureau of Land Management, National Park Service, Bureau of Indian Affairs, Environmental Protection Agency, National Biological Service, Fish and Wildlife Service, Department of Defense, and other appropriate agencies. We further recommend the Soil Conservation Service take the lead in organizing this partnership effort. The working group should be charged with establishing the criteria for this assessment. As a minimum, the data to be collected and reported in the assessment should be the Site Conservation Rating (SCR). The ecological site concept must be the cornerstone of this inventory. We recommend to the Board of Directors that the Executive Vice President communicate with the heads of the above agencies to encourage their initiation of and support for the interagency working group through a Memorandum of Agreement or other appropriate method to accomplish the task at hand.

2. Educational Programs UCT recommended that the Board of Directors provide an effective educational program to ensure understanding by SRM members, agencies, and others of the principles and terms described in the Task Group Report.

3. Research Needs In its 1991 report UCT made some general recommendations on research needs relating to the guidelines it had developed. In July 1993, in response to a request for more explicit statements on research needs from the Research Affairs Committee, the UCT identified the following research needs:

a. Identify an appropriate set of attributes and the techniques for monitoring these attributes for key ecological sites, including those in riparian areas, and evaluate these attributes in relationship to the site conservation threshold (SCT).

b. Characterize the soils, particularly the upper soil layers, and determine the relationship of soil characteristics to plant community stability and the site conservation threshold (SCT).

c. Investigate seasonal and annual changes in weather, soil, and vegetation attributes as they relate to the site conservation threshold (SCT).

d. Identify major plant community types that typify ecological sites and describe the ecological processes and management actions associated with transitions among these types.

e. Develop methodology to integrate measures of the SCT across a mosaic of ecological sites at the landscape level to determine the status of rangelands at the watershed, basin, or regional scale.

f. Investigate the relationship of plant diversity, as measured by life form, class and species structure, to the SCT and the stability of plant communities.

\section{CONCLUSION}

West et al. (1994) reviewed present methods of assessing rangeland condition and changes which may occur as a result of changing objectives, new technology, and new concepts. A guiding premise of the UCT has been that concepts and methodology of rangeland condition assessment must change and adapt as new knowledge and understanding is acquired. Each new effort to improve upon past methods is only an "approximation" which awaits further change and improvement. The guidelines put forth by the UCT may be altered in the future by the Society for Range Management. Such changes should be based on science and feasibility of field application.

\section{LITERATURE CITED}

Blackburn, W.H., T.L. Thurow, and C.A. Taylor, Jr. 1986 Soil crosion on rangeland, pp 31-39 $\mathrm{m}$ : Proc. Use of Cover, Soils and Weather Dâta in Range. Monitor. Symp. Soc. Range Manage., Denver, Colo.

BLM. 1979. Managing the public rangelands-public review draft. Bur. Land Manage. U.S. Dep. Int.

Clements, F.E. 1905. Research methods in ecology. Univ. of Nebr. Publ. Co., Lincoln, Nebr.

Clements, F.E. 1916. Plant succession. Carnegie Inst. Washington, D.C., Pub. 242.

Comptroller General. 1977. Public rangelands continue to deteriorate. U.S. Gen. Accounting Off. Rep. CED-77-88. Washington, D.C.

Dregne, H. E. 1983. Desertification of arid lands. Harwood Academic Publ. N.Y

Dyksterhuis, E. J. 1949. Condition and management of rangeland based on quantitative ecology. J. Range Manage. 2:104-115.

Ellison, L. 1949. The ecological basis for judging condition and trend on mountain rangeland. J. For. 47:785-795.

Friedel, M. H. 1991. Range condition assessment and the concept of threshuld -a viewpoint. J. Range Manage. 44:422-426.

Frost, W. E., and E. L. Smith. 1991. Biomass productivity and range condition on range sites in southern Arizona. J. Range Manage. 44:6467.

Holling, C.S. 1973. Resiliency and stability of ecological systems. Annu. Rev. Ecol. Syst. 4:1-23. 
Jameson, D. A. 1970. Land management policy and development of ecological concepts. J. Range Manage. 23:316-321.

Johnson, H. B., and H. S. Mayeux. 1992. Viewpoint: A view on species additions and deletions and the balance of nature. J. Range Manage. 45:322-333.

Laycock, W.A. 1991. Stable states and thresholds of range condition on North American rangelands-a view point. J. Range Manage. 44:427433.

Laycock, W.A. 1994. Implications of grazing vs. no grazing on today's rangelands. pp. 250-280 $\mathrm{h}$ : M. Vavra. W.A. Laycock, and R.D. Pieper (eds.) Ecological implications of livestock herbivory in the West. Soc. Range Manage. Denver. Colo.

Love, R. M. 1961. The range-natural plant communities or modified ecosystems? J. Brit. Grassl. Soc. 16:89-99.

NRC. 1994. Rangeland health-new methods to classify, inventory and monitor rangelands. Nat. Res. Counc. Nat. Acad. Press. Washington, D.C.

Noy-Meir, I., and B.H. Walker. 1986. Stability and resilience in rangelands. pp. 21-25. In: J.Joss, P. W. Lyneh, and O.B. Williams (eds.) Rangelands: A resources under siege-Proc. of the Second Int. Rangeland Congr.. Australian Acad. of Sci. Canberra.

Parker, K. W. 1954. Application of ecology in the determination of range condition and trend. J. Range Manage. 7:14-23.

RISC. 1983. Guidelines and terminology for range inventories and monitoring. Rep. of the Range Inventory Standardization Committee. Soc. Range Manage. Denver, Colo.

Sampson, A. W. 1919. Plant succession in relation to range management. U.S. Dep. Agr. Bull. 791.76 p.

Severson, Keith E., and Philip J. Urness. 1994. Livestock grazing: a tool to improve wildlife habitat. pp. 232-249 In: M. Vavra, W.A. Laycock, and R.D. Pieper (eds.). Ecological Implications of Livestock Herbivory in the West. Soc. Range Manage. Denver, Colo.

Smith, E. L. 1978. A critical evaluation of the range condition concept. pp 266-267. In: D.N. Hyder (ed). Proc. First Int.Rangeland Congr. Soc. Range Manage. Denver, Colo.

Smith, E.L. 1989. Range condition and secondary succession: a critique. pp 103-141 In: W.K. Lauenroth and W.A. Laycock (eds). Secondary succession and the evaluation of rangeland condition. Westview Press. Boulder, Colo.

Society for Range Management. 1989. Assessment of rangeland condition and trend of the United States. Society Range Manage. Denver, Colo.

Stoddart, L. A., A. D. Smith, and T. W. Box. 1975. Range management. MeGraw-Hill. New York, N.Y.

Tongway, David. 1994. Rangelind soil condition assessment manual. C.S.I.R.O. Div. of Wildl. and Ecol. Canberra.

Unity in Concepts and Terminology Task Group. 1991. New directions in range condition assessment. Report of the Task Group on Unity in Concepts and Terminology. Soc. Range Manage. Denver, Colo.

USDI/USDA. 1994. Rangeland reform '94. Draft environmental impact statement. U.S. Dep. Int..

Wald, J. and D. Alberswerth. 1985 Our ailing rangelands-condition report 1985. Nat. Wildl. Fed, and Nat. Resourc. Def. Counc. Washington, D.C.

Walker, B.H., D. Ludwig, C.S. Holling, and R.M. Peterman. 1981. Stability of semi-arid savannah grazing systems. J. Ecol. 69:473-498.

Watters, Susan E. 1993. Site stability assessment on a clay loam upland range site. M.S. Thesis. Univ. of Arizona. Tucson.

West, N. E. 1993. Biodiversity of rangelands. J. Range Manage. 46:2-13.

West, N.E., Kirk McDaniel, E. Lamar Smith, Paul T. Tueller, and Stephen Leonard. 1994. Monitoring and interpreting ecological integrity on arid and semi-arid lands of the Western United States. New Mexico Range Improvement Task Force Rep. 37. New Mexico State Univ., Las Cruces.

Westoby, M. 1980. Elements of a theory of vegetation dynamics in rangelands. Israeli J. Botany 28:169-194.

Westoby, M., B. Walker, and I. Noy-Meir. 1989. Opportunistic management for rangelands not at equilibrium. J. Range Manage. 42:266274.

\section{APPENDIX A}

The Task Group identified all the terms in the SRM Glossary (Glossary Revision Special Committee 1989) and the RISC report (RISC 1983) which it considered relevant to the concepts and methodology of rangeland inventory, evaluation, and monitoring. The definition of each term was considered. When the definition in the SRM Glossary or the RISC report was considered adequate it was retained. If neither the Glossary or RISC definition was considered consistent with the principles and concepts adopted by the Task Group, another published definition was sought. If no existing definition was considered sufficiently accurate and consistent with the Task Group's recommendations, a new or revised definition was developed. Each term defined below is referenced as to the source. Some terms in the Glossary were recommended for exclusion from the Glossary either because they were considered redundant or were considered terms which are not necessary to be defined by the Society for Range Management.

The Task Group recommends the following terms and definitions for inclusion in the next revision of the SRM Glossary.

Apparent trend (Task Group)

- an interpretation of trend based on observation and professional judgement at a single point in time.

Bare ground (RISC)

- all land surface not covered by vegetation, rock, or litter. (c.f. ground cover)

Biomass (RISC)

- the total amount of living plants and animals above and below ground in an area at a given time.

\section{Browse (RISC)}

- (n) the part of shrubs, woody vines and trees available for animal consumption. (v) to search for or consume browse.

Canopy cover (RISC)

- the percentage of ground covered by a vertical projection of the outermost perimeter of the natural spread of foliage of plants. Small openings within the canopy are included. It may exceed $100 \%$. (Syn. crown cover).

\section{Carrying capacity (Task Group)}

- the average number of livestock and/or wildlife which may be sustained on a management unit compatible with management objectives for the unit. In addition to site characteristics, it is a function of management goals and management intensity.

Climax (Odum 1971)

- the final or stable biotic community in a successional series; it is self-perpetuating and in equilibrium with the physical habitat.

Community (Task Group)

- a general term for an assemblage of plants and/or animals living together and interacting among themselves in a specific location; no particular ecological status is implied.

Community type (Task Group)

- an aggregation of all plant communities with similar structure and floristic composition. A unit of vegetation within a classification with no particular successional status implied. 
Comparison area (RISC)

- an area with a documented history and/or condition that is used as a standard for comparison.

Critical area (RISC)

- an area which must be treated with special consideration hecause of inherent site factors, size, location, condition, values, or significant potential conflicts among uses.

Cryptogam (RISC)

- a plant in any of the groups Thallophytes, Bryophytes, and Pteridophytes -mosses. lichens and ferns.

Decreaser (Task Group)

- for a given plant community, those species that decrease in amount as a result of a specific abiotic/biotic influence or management practice.

Density (RISC)

- numbers of individuals or stems per unit area (Density does not equate to any kind of cover measurement).

Desired plant community (Task Group)

- of the several plant communities that may occupy a site, the one that has been identified through a management plan to best meet the plan's objectives for the site. It must protect the site as a minimum.

Dominant (Glossary)

- (1) plant species or species groups, which by means of their number, coverage, or size, have considerable influence or control upon the conditions of existence of associated species. (2) those individual animals which, by their aggressive behavior or otherwise, determine the behavior of one or more animals resulting in the establishment of a social hierarchy.

Ecological site (Task Group)

- a kind of land with specific physical characteristics which differs from other kinds of land in its ability to produce distinctive kinds and amounts of vegetation and in its response to management. Apparently synonymous with ecological type used by USFS.

Ecological type (Task Group)

- syn. of ecological site.

Foliar cover (RISC)

- the percentage of ground covered by the vertical projection of the aerial portion of plants. Small openings in the canopy and intraspecific overlap are excluded. Foliar cover is always less than canopy cover; either may exceed $100 \%$.

Forage (RISC)

- (n) browse and herbage which is available and may provide food for grazing animals or be harvested for feeding. (v) to search for or consume forage.

Frequency (Glossary)

- the ratio between the number of sample units that contain a species and the total number of sample units.

Gravel, Cobble, Stones (RISC)

- as defined in Soil Taxonomy (Soil Conservation Service 1975): gravel ( 2 mm-3 inches), cobble (3-10 inches), stones (over 10 inches). (Note: For standard range inventory procedures it is recommended that gravel smaller than $5 \mathrm{~mm}$ in diameter be classed as bare ground in cover determinations.)
Grazing capacity (Task Group)

- syn. with carrying capacity.

Ground cover (RISC)

- the percentage of material, other than bare ground, covering the land surface. It may include live and standing dead vegetation, litter, cobble, gravel, stones and bedrock. Ground cover plus bare ground would total $100 \%$.

Habitat type (Task Group)

- the collective area which one plant association occupies or will come to occupy as succession advances. The habitat type is defined and described on the basis of the vegetation and its associated environment. The concept was developed by Rexford Daubenmire. Habitat type is similar in concept to ecological site. The difference depends mainly on how specifically plant associations are defined. Habitat type is often misused to refer to classification of vegetation or wildlife habitat rather than a land classification.

Herbage (RISC)

- the above-ground material of any herbaceous plant.

Historical climax (Task Group)

- the plant community considered to best typify the potential plant community of an ecological site prior to the advent of European man. May no longer be one of the potential plant communities for the site.

Increaser (Task Group)

- for a given plant community, those species that increase in amount as a result of a specific abiotic/biotic influence or management practice.

Key area (RISC)

- a relatively small portion of a range selected because of its location, use, or grazing value as a monitoring point for grazing use. It is assumed that key areas, if properly selected, will reflect the overall acceptability of current grazing management over the range.

Key species (RISC)

- (1) forage species whose use serves as an indicator to the degree of use of associated species. (2) those species which must, because of their importance, be considered in the management program.

Leaf area index (RISC)

- sum of total leaf area expressed as a percentage of ground surface. Leaf area index may exceed $100 \%$.

Litter (RISC)

- the uppermost layer of organic debris on the soil surface; essentially the freshly fallen or slightly decomposed vegetal material.

Mulch (Glossary)

- (n.) (1) a layer of dead plant material on the soil surface. (cf. fresh and humic mulch) (2) an artificial layer of material such as paper or plastic on the soil surface. (v) cultural practice of placing rock, straw, asphalt, plastic or other material on the soil's surface as a surface cover.

Pioneer (species) (Webster's New Collegiate dictionary) - a plant or animal capable of establishing itself in a bare or barren area and initiating an ecological cycle. 
Plant association (RISC)

- a kind of climax plant community consisting of stands with essentially the same dominant species in corresponding layers.

Plant community (Task Group)

- an assemblage of plants occurring together at any point in time, thus denoting no particular ecological status. A unit of vegetation.

Plant community type

- see Community type

Plant succession (Task Group)

- vegetation change.

Potential natural community

- see Potential natural vegetation.

Potential natural vegetation (Task Group)

- an historical term originally defined by A.W. Kuchler as the stable vegetation community which could occupy a site under current climatic conditions without further influence by man. Often used interchangeably with Potential Natural Community.

Potential plant community (Task Group)

- one of usually several plant communities that may become established on an ecological site under the present environmental conditions, either with or without interference by man.

Range condition (Task Group)

- Historically, has usually been defined in one of two ways: (a) a generic term relating to present status of a unit of range in terms of specific values or potentials. Specific values or potentials must be stated. (b) the present state of vegetation of a range site in relation to the climax (natural potential) plant community for that site. It is an expression of the relative degree to which the kinds, proportions, and amounts of plants in a plant community resemble that of the climax plant community for the site.

Range condition class (Task Group)

- one of a series of arbitrary categories used to classify range condition as that term has been variously defined. See range condition.

Range degradation (Task Group)

- the process that leads to an irreversible reduction in capability of an ecological site to produce vegetation.

Range improvement (Public Law 95-514 Sec 3f)

- any activity or program on or relating to rangelands which is designed to improve production of forage, change vegetation composition, control patterns of use, provide water, stabilize soil and water conditions, or provide habitat for livestock and wildlife.

Rangeland inventory (RISC - range inventory)

- (v) the systematic acquisition and analysis of resource information needed for planning and for management of rangeland. (n) the information acquired through range inventory.

Range site (Task Group)

- syn. of ecological site on rangeland.

Range type (predom. RISC)
- an historical term that refers to, and only to, the 18 standard range vegetation types recognized by the 1937 Task Force (Interagency Range Survey Committee, 1937).

Resource value rating (Glossary)

- the value of vegetation present on an ecological site for a particular use or benefit. Resource value ratings may be established for each plant community capable of being produced on an ecological site including exotic or cultivated species.

Retrogression (Task Group)

- an historical term used by some ecologists to mean succession in reverse. According to Clements (1916), however, retrogression is synonymous with destruction and denudation of a community.

Seral community (Odum 1971)

- the relatively transitory communities which develop under ecological succession. (syn. seral stage)

Seral stages (Odum 1971)

- the relatively transitory communities which develop under ecological succession. (syn. seral communities)

Sere (Odum 1971)

- the whole series of communities which develop in a given situation during ecological succession.

Site conservation rating (Task Group)

- an assessment of the protection afforded a site by the current vegetation against loss of potential. SCR greater than Site Conservation Threshold is considered a "satisfactory" SCR and below SCT is considered an "unsatisfactory" SCR.

Site conservation threshold (Task Group)

- the kind, amount and/or pattern of vegetation needed as a minimum on a given site to prevent accelerated erosion.

Species composition (Glossary)

- the proportions of various plant species in relation to the total on a given area. It may be expressed in terms of cover, density, weight, etc.

Trend (Task Group)

- the direction of change in an attribute as observed over time.

Usable forage (RISC)

- that portion of the forage that can be grazed without damage to the basic resources; may vary with season of use, species, and associated species.

Vegetation management status (Task Group)

- the relative degree to which the kinds, proportions, and amounts of vegetation in the present plant community resemble the desired plant community chosen for an ecological site.

Vegetation type (RISC)

- a kind of existing plant community with distinguishable characteristics described in terms of the present vegetation that dominates the aspect or physiognomy of the area.

The Task Group recommends that the following terms be deleted from the glossary for the reasons stated:

Allowable use - not needed: proper use will suffice.

Condition class - not needed; see range condition class

Degenerated range- not needed. 
Deteriorated range - not needed.

Ecological status- misleading; if concept is needed, should be successional status

Invader - included in definition of increaser.

Livestock forage condition - use resource value rating concept.

Measured trend - not needed; trend is defined.

Monitoring - not a range management term; use dictionary

Range retrogression - misleading; retrogression is defined.

Range suitability - not needed.

Range trend - not meaningful; trend occurs in attributes of the range.

Series - not a range management term; use botanical or soils definitions.

Soil condition class - not useful under present guidelines.

Stable - use a dictionary.

Stand - use botanical definitions.

Succession - see plant succession.

Suitability - use a dictionary.

Suitable range - not necessary.

Unsuitable range - not necessary.

Zone - use a dictionary.

\section{APPENDIX B ECOLOGICAL SITE DESCRIPTION}

A technical description is to be prepared for each Ecological Site that is identified and named. Descriptions should be brief, but should clearly represent the features that characterize the site. They are to address all the resources of the site that are important for planning, managing, and monitoring rangeland resources. These descriptions will include the following, as appropriate, along with other pertinent information.

\section{A. Heading.}

All ecological site descriptions will identify department and agency, region, MLRA, state, area, and /or local office.

1. Full name. The full name of the site should be placed on each page of the description.

2. Ecological Site Identification.

B. Site Characterization.

Describe unique characteristics, features, and/or locations on the landscape which will assist in the recognition of the site.

C. Physiographic Features.

1. Occurrence of site in the landscape, e.g., on ridgetops, in swales, on south-facing slopes. Special notations should be made concerning susceptibility to surface water run-on and overflow, depth of water tuble, and similar characteristics.

2. Degree and direction of slopes.

3. Range in elevation

D. Climatic Features

1. Frost-free period.

2. Freeze-free period.

3. Mean annual precipitation.

4. Mean annual air temperature.

5. Mean annual soil temperature.

6. Monthly moisture and temperature distribution.

7. Other climatic features such as storm intensity, wind velocity, and drouglt cycles that typify the site and relate to its potential. Climatic information should be developed and included in the description of the site. It can be refined for a field office or other logical geographical area where the site occurs.

E. Soils

1. Soils narrative. Briefly describe the main properties of the major soils associated with the site. Give special attention to properties that significantly affect plant, soil, and water relationships.

2. Name the major soils associated with the site. If many soil names are subject to change, list the soil taxonomic units associated with the site on a separate sheet that can be easily updated.

F. Major Identifiable Plant Communities and Associated Animal Species

1. Describe each major identifiable plant community type that may occupy this site, including the representative natural plant community, if known.

2. For each of the community types, list the major plant species and the amount or proportion of life forms of functional groups, expressed as annual production (e.g., dry weight per unit area) and/or other appropriate measures, in the total plant community. Species should be listed by National Scientific Plant Symbol and common name. for cryptogamic communities (mosses and lichens), enter the same data as above. Production of cryptogamic communities is expressed as total production, not annual production.

3. Describe ground cover and structure for each communitytype.

a. Typical percent canopy cover. Ground cover is the percentage of the ground covered from the vertical view in order of plant stratification. This will often exceed $100 \%$.

b. Average height. List the average height for each level of the stratification.

c. Expected range in basal cover. Basal cover is the percentage of the ground surface actually occupied by vascular vegetation. Litter, coarse fragments (rocks), bare ground, and vascular vegetation basal cover will equal $100 \%$.

4. Total Annual Production. Show total annual production as median dry-weight and the fluctuations to be expected during favorable, average, and unfavorable years.

G. Ecological dynamics.

Briefly describe the common community patterns of successional shifts or change and list plant species that are most likely to increase or invade as communities change. Examples of these types of community changes are the effects of grazing animals, fire or the suppression of fire, extended drought, or other management practices or natural influences. Describe the transition pathway, including known causes of plant community change. Identify plant community types which are not sustainable because they will not adequately protect the site from accelerated soil erosion.

H. Other Site Characteristics.

This section will contain other pertinent information such as:

1. Hydrologic data

2. Visual attributes

3. Etc. 


\section{Site Conservation Rating}

Identify the criteria to be used in evaluating degree of site stability and threshold values to assess the site conservation threshold.

J. Site Documentation.

1. Associated sites. Identify and describe the sites that are commonly located in conjunction with the site.

2. Similar sites. Identify and describe sites that resemble or can be confused with the site.

3. Supporting data for site development. Include historical records, rangeland site data, and field documentation.
4. Typical site location. Location of a typical or benchmark example of the site and typical representatives of the plant communities which can occur on the site. Indicate township, section, longitude, latitude, general location, plant community, and date of description.

5. Site developer, date, and approval.

Information from this ecological site description can be used to develop ecological site interpretations for various uses and values. 


\section{Journal of Range Management \\ Peer Reviewers \\ 1994}

Theodore E. Adams, Jr.

Glen Aiken

Phil S. Allen

Gerald Anderson

Dean Anderson

R. James Ansley

K.H. Asay

Dennis Austin

Derek Bailey

John Baker

Roger Banner

William Berg

James Berger

D.J. Bernardo

Marty Beutler

Terrance G. Bidwell

Wilbert Blackburn

R.E. Blackshaw

Arvid Boe

D. Terrance Booth

Thomas W. Boutton

Rodney W. Bovey

Rudy Bowman

Tom Bragg

Mark Branine

David D. Briske

Carlton Britton

Joe Brummer

Evelyn Bull

Steve Bunting

Elizabeth Burritt

Jim Carr

Joel Caton

Jeanne Chambers

David Clark

Thomas Clausen

Robert Cochran

Will Cohen

Samuel Coleman

J. Richard Conner

D. Layne Coppock

Jerry Cox

Charles Davis

Ronald Delany

Tim DelCurto

Steve Demarais

Ed DePuit

Dale Devitt

Jerry Dodd

Paul Doescher

Randy L. Dovel

William A. Dugas

Lee Eddleman

William E. Emmerich

David Engle

Rick Estell

Walt Fick
David Forbes

A.B. Frank

Ed Fredrickson

Margaret Friedel

William E. Frost

Tim Fulbright

David Ganskopp

Didier Genin

Robert Gibbens

Robert Gillen

Gerald Gottfried

Richard Grant

Elaine Grings

Fred Guthrey

Richard Hart

Pat Hatfield

Philip Heilman

Rod Heitschmidt

Scott Henke

Edward Heske

Ralph A. Hicks

N. Thompson Hobbs

Lenat Hofman

Jerry Holechek

Gerald Horn

William Hunt

George Hurst

E.A. Johnson

Pat Johnson

Richard C. Johnson

Michael Karl

S. Karl

John Kie

Robert J. Kinucan

Bill Knight

Mort Kothmann

Eugene Krenzer

Scott Kronberg

William Krueger

John Lacey

David Lambert

Larry L. Larson

Don J. Latham

William K. Lauenroth

Karen Launchbaugh

Bill Laycock

Wayne C. Leininger

David Leslie

Roland Line

Jeffry Lockwood

William Longland

Scott Lutz

Michael MacNeil

Robert Masters

Herman Mayeux

Hank Mayland

Mitch McClaran
Ted McCollum

Kirk McDaniel

Mike McInnis

Guy McPherson

Daniel Milchunas

Wally Miller

John Mitchell

Ron Mitchell

Stephen B. Monsen

Jack Morgan

Jeff Mosely

L.E. Moser

Jeff Mullahey

G.A. Murray

David Nelson

Michael Norland

Robert Nowak

Fred Obermiller

Bret Olsen

Ken Olsen

Keith Owens

Clint Owensby

Michael Panciera

Thomas Papachristou

David Patterson

James M. Peek

Rex Pieper

William Pinchak

W.D. Pitman

Glenn E. Plumb

H. Wayne Polley

J.F. Power

Fred Provenza

David Pyke

William Pyle

Mike Ralphs

Darrell Rankins

John Read

Ed Redente

Larry Redmon

Pat Reece

Jean Reeder

Ken Renard

Kevin J. Rice

Ron Ries

Bob Riggs

Larry R. Rittenhouse

Jim Romo

Roger Rosentretor

Bruce Roundy

George Ruyle

David Sanson

Walter Schacht

Joe Schuster

Christa Schwintzer

Nancy Shaw

Dennis Sheehy
Phil Sims

Mike Smith

Bok Sowell

Ken Spaeth

Everett Springer

Tim Springer

Rich Stock

Darryl G. Stout

Jim Stritzke

Jerry Stuth

Sherman Swanson

Robin Tausch

C.A. Taylor, Jr.

Tom Thurow

Charles Tischler

L. Allen Torell

Paul Tueller

Monica Turner

Scott Tyler

Darrel Ueckert

Cornelius H.M. van Bavel

Nicholas Van Pelt

Larry Van Tassel

Martin Vavra

Donald Vieton

Ken Vogel

Jerry Volesky

Fred Wagstaff

Linda Wallace

John Walker

John Warwick

Bruce Welch

Neil West

David Wester

Mark Westoby

Larry M. White

Steve Whisenant

Richard Whitney

Randy Wiedmeier

J. Ross Wight

Stephen Williams

John Workman

James A. Young

Ben Zamora 